\title{
The Asymmetric Effects of Oil Price Changes on the Economic Activities in Indonesia
}

\author{
Rina Juliet Artami ${ }^{1}$, Yonosuke Hara ${ }^{2}$
}

\begin{abstract}
This paper analyzes the asymmetric impact of oil price changes on the economic growth of and inflation in Indonesia by using the vector autoregression (VAR) model for the period from 1990Q1 to 2016Q4. The results show that the impact of oil price changes on the gross domestic product (GDP) is asymmetric, as a drop in oil prices decreases the GDP, whereas an increase in oil prices does not significantly affect GDP. It is crucial for Indonesia to reduce its dependency on oil, mainly as its primary source of revenue, and also consider utilizing more sources of renewable energy. At the same time, the effects of both the positive and negative changes in oil prices are found to be not statistically significant to inflation. The lack of impact of oil price changes on inflation can explain by the implementation of the fuel price subsidy in Indonesia.
\end{abstract}

Keywords: oil price, gross domestic product, inflation, VAR model

\begin{abstract}
Abstrak
Penelitian ini bertujuan untuk menganalisis dampak asimetris perubahan harga minyak terhadap pertumbuhan ekonomi dan inflasi di Indonesia dengan menggunakan model vector autoregression (VAR) untuk periode dari tahun 1990 kuartal I sampai dengan tahun 2016 kuartal IV. Hasil penelitian menunujukkan bahwa pengaruh perubahan harga minyak terhadap produk domestik bruto (PDB) adalah asimetris, yaitu penurunan harga minyak secara signifikan menurunkan PDB, sedangkan kenaikan harga minyak tidak secara signifikan mempengaruhi PDB. Upaya untuk menurunkan ketergantungan terhadap minyak dibutuhkan oleh Indonesia, khususnya penurunan kontribusi minyak sebagai sumber pendapatan negara, serta dengan meningkatkan penggunaan energi terbarukan. Sementara itu, perubahan harga minyak, baik penurunan maupun kenaikan harga minyak, tidak mempengarubi inflasi secara signifikan. Tidak terdapatnya pengaruh perubahan harga minyak terhadap inflasi disebabkan oleh adanya kebijakan subsidi bahan bakar minyak di Indonesia.
\end{abstract}

Kata Kunci: harga minyak, produk domestik bruto, inflasi, model VAR

\section{How to Cite:}

Artami, R.J. \& Hara, Y. (2018). The Asymmetric Effects of Oil Price Changes on the Economic Activities in Indonesia. Signifikan: Jurnal Ilmu Ekonomi. Vol. 7 (1): 59 - 76. doi: http//dx.doi.org/10.15408/sjie.v7i1.6052 


\section{Introduction}

Oil is an important energy source that plays a vital role in an economy due to its extensive use as fuel and raw material for production (Chang \& Wong, 2003; Rafiq et al., 2009). Therefore, oil price fluctuations may affect economic condition of all countries. Earlier studies such as Hamilton (1983) have linked oil price, economic growth, and inflation. As oil price also accounts for the input cost of production, its increase would affect the total cost of production (Brown \& Yücel, 2002). Increased oil prices result in higher input costs and lower input supply, which in turn decrease the total output leading to the decrease in economic productivity. The reduction in productivity results in decline in real wage and the increase of unemployment rates leading to higher inflation in an economy.

Later studies extend the argument to point out that economic activities could respond asymmetrically to changes in oil prices (Hamilton, 1996; Lee et al., 1995; Mork, 1989). The effect of the same change in price does not have the same magnitude when the change is positive as compared to when the change is adverse. This finding is significant because it can capture the impact of both upward and downward changes in oil prices. However, the empirical evidence of such asymmetry is mixed. Mork (1989), Lee, et al. (1995) and Hamilton (1996) agreed that positive changes in oil price had a negative impact on economic activities. The results of the asymmetric impact of oil price changes on the economic growth of and inflation in emerging countries and Asian countries could not conclude in this study. On the asymmetric effects of oil price changes, both the Iranian and the China economies were more sensitive to the downward changes in oil price than to the upward changes in oil price (Du et al., 2010; Farzanegan \& Markwardt, 2009). Meanwhile, Jbir and Zouari-Ghorbel (2009) found that the asymmetric impact of oil price changes did not exist because both linear and non-linear changes in oil price affected the Tunisian economy in the same way.

Brown and Yücel (2002) state factors such as monetary policy, adjustment costs, and petroleum product prices as an alternative explanation for the cause of asymmetric impact. First, the monetary policy can cause an asymmetric effect of oil price changes on the economic activity due to the increase or decrease of unemployment and inflation rates. The asymmetry can occur when the combination of these factors cannot keep the nominal GDP constant due to unexpected inflation and disinflation precipitated by the monetary policy. Second, the adjustment costs that come from sectoral imbalances, coordination problems between firms, or differential input ratio need more time to be adjusted due to the oil price changes. The unemployment caused by rising oil prices will happen because the adjustments between the contraction of sectors dependent on energy and the expansion of sectors less dependent on energy need more time to achieve. Last, the asymmetric impact of oil price changes can also cause by the different price changes of petroleum products to the changes in crude oil price due to the different policy applicable to petroleum product prices such as fuel subsidy.

Although oil price fluctuations may seem more important for developed economies with their advanced industrial sector, emerging economies show an increasing dependency on oil (Rafiq et al, 2009). For instance, Indonesia being a developing country is dependent on oil to develop its economy, as oil highly contributes to its gross domestic product (GDP) and significantly affects its total trade balance and government expenditure. 
Table 1. Oil Statistics of Indonesia

\begin{tabular}{lllllll}
\hline & 1990 & 1996 & 2000 & 2005 & 2010 & 2015 \\
\hline $\begin{array}{l}\text { Total Proved Reserves } \\
\text { (Thousand Million Barrels) }\end{array}$ & 5.4 & 4.7 & 5.1 & 4.2 & 4.2 & 3.6 \\
$\begin{array}{l}\text { Production } \\
\text { (Thousand Barrels Daily) }\end{array}$ & 1539 & 1580 & 1456 & 1096 & 1003 & 825 \\
$\begin{array}{l}\text { Consumption } \\
\text { (Thousand Barrels Daily) }\end{array}$ & 653 & 924 & 1139 & 1303 & 1402 & 1628 \\
\hline
\end{tabular}

Source: BP Statistical Review of World Energy, 2016.

Indonesia was earlier known as a net oil exporting country and depended on oil as its primary source of revenue. However, since 2005, Indonesia has transformed from a net oil exporting country to a net oil importing country with reduced oil contributions to its income, resulting from the oil production decline due to the depletion of resources. Table 1 contains Indonesia's oil statistics. The statistics show that Indonesia's proved crude oil reserves in 2015 were $30 \%$ lower than that in 1990 , causing the production to decline by $50 \%$ and the revenue to decrease when measured as the percentage of total GDP as shown in Table 2.

Table 2. Proportions of Oil Revenue and Fuel Subsidy of Total GDP

\begin{tabular}{|c|c|c|c|c|c|c|}
\hline & 1990 & 1996 & 2000 & 2005 & 2010 & 2015 \\
\hline Oil Revenue & 7.88 & 2.78 & 5.01 & 3.89 & 2.65 & 0.85 \\
\hline \multicolumn{7}{|l|}{ (\% of GDP) } \\
\hline $\begin{array}{l}\text { Consumption } \\
\text { (Thousand Barrels Daily) }\end{array}$ & 1.62 & 0.27 & 3.87 & 3.45 & 2.17 & 0.53 \\
\hline
\end{tabular}

Note. Oil revenue included oil tax since 2000. The data adapted from Statistics Indonesia, 2015.

This transformation has led to a deficit balance of trade in the oil and gas sector in Indonesia since 2005, as shown in Table 3. This deficit balance of trade in oil and gas sector has also resulted from the increasing trend of oil consumption. Oil's share in Indonesia's primary energy mix was targeted to be $40 \%$ in 2015 , indicating its heavy dependence on oil (National Energy Council, 2015). In numbers, oil consumption in Indonesia has doubled since 1990 as shown in Table 1. Thus, both the reduction in production and the increasing demand for oil explain the growing deficit balance of trade in the oil and gas sector.

Oil's share in Indonesia's government expenditure is also substantial. Fuel subsidy has been a burden on Indonesia's national budget over the years as shown in Table 2. Under this subsidy scheme, fuel products are sold for a fixed price below the market price (market price based on the international oil price) and determined by the government. Therefore, the Indonesian government has made an effort to reduce fossil fuel subsidies by eliminating the subsidy for some of the petroleum products gradually and linking it with the international oil price. However, this has resulted in fuel product price fluctuations in Indonesia by the global oil price fluctuations, and this can potentially lead to inflation. The reform in fuel 
subsidy started at the end of 2014 due to a sharp decrease in world oil price, resulting in a more significant decrease of fuel subsidies proportionately to the GDP as shown in Table 2.

Table 3. Total Balance of Trade of Oil and Gas in Indonesia

\begin{tabular}{lllllll}
\hline & 1990 & 1996 & 2000 & 2005 & 2010 & 2015 \\
\hline Export & 11.07 & 11.72 & 14.37 & 19.23 & 28.04 & 18.57 \\
$\begin{array}{l}\text { (Billion US\$) } \\
\begin{array}{l}\text { Import } \\
\text { (Billion US\$) }\end{array}\end{array}$ & 1.92 & 3.60 & 6.02 & 17.46 & 27.41 & 24.61 \\
\hline
\end{tabular}

Source: Statistics Indonesia, 2017.

Oil price changes have been found to affect GDP and inflation. Specifically, there is evidence that the impact of oil price fluctuations on GDP and inflation is asymmetric. However, there is no general agreement on the findings of the asymmetric effect of oil price fluctuations on GDP and inflation. Furthermore, there is evidence that Indonesia is highly dependent on oil, and the study on the asymmetric impact in the case of Indonesia has not yet established. Therefore, it is imperative to conduct such a survey in the case of Indonesia. Thus, this paper aims to fill this gap in the literature and attempts to investigate the asymmetric impact of oil price fluctuations on the GDP of and inflation in Indonesia. If confirmed, policy recommendations that will be provided to overcome the economic condition in Indonesia when oil price decreases and increases will be more specific.

\section{Method}

This paper uses the quarterly data from 1990Q1 to 2016Q4 of Indonesia. The coverage starts in the first quarter of 1990 because the earlier data for most of the variables are not available. This paper uses three macroeconomic variables. The first is the real gross domestic product (rgdp, real GDP at the constant price of the year 2010 in billion Rupiah). The second variable is inflation that represented by the consumer price index (cpi, consumer price index at the constant price of the year 2010). The last variable is the real oil price (rop, Indonesian crude oil price in US\$ per Barrel).

The three variables used in the VAR model are processed differently before they are included in the analysis. Following the methods used by Mork (1989) and Cunado and Gracia (2005), the variable of oil price is separated into negative and positive changes in order to test the asymmetric effects of oil price changes. First, both the negative and positive changes in oil price are employed in real terms by deflating the oil price with the consumer price index at the constant price of the year 2010, and then it is transformed into natural logarithms. Next, the real oil price in the natural logarithmic form rop will be transformed into quarterly changes in the real oil price in the natural logarithmic form $\left(\Delta r o p_{t}=\operatorname{In} r o p_{t}-\operatorname{In} r o p_{t-1}\right)$. Then, the quarterly changes in the real oil price in the natural logarithmic form will be separated into two groups-increase or decrease. The positive and negative changes in the real oil price in the natural logarithmic form will be treated as follows: 


$$
\begin{aligned}
\Delta r o p_{t}^{+} & =\Delta r o p_{t} & & \text { if } \Delta r o p_{t}>0 \\
& =0 & & \text { otherwise } \\
\Delta r o p_{t}^{-} & =\Delta r o p_{t} & & \text { if } \Delta r o p_{t}<0 \\
& =0 & & \text { otherwise }
\end{aligned}
$$

The separation results in the positive and negative changes in the real oil price in the natural logarithmic form (ln_rop_pos and ln_rop_neg). The GDP in real terms is obtained directly from Statistics Indonesia and then transformed into natural logarithms (ln_rgdp), whereas the consumer price index (cpi) is directly obtained from the International Financial Statistics database without any transformation. The method employed in this paper is the vector autoregression model (VAR) in order to investigate the asymmetric impact of oil price changes on GDP and inflation. In general, a VAR model is used for forecasting. The VAR model shows that the current value of a variable is forecasted by the past values of both the own and other variables. First, a VAR model is specified and estimated. After that, the VAR model can be used directly to forecast. The other purposes of a VAR model are to analyze the Granger causality and structural form by implementing both the impulse response functions and forecast error variance decomposition.

While conducting a time series analysis, one should first perform a stationarity test to determine whether the probability distribution of the series is time-invariant or mean, the variance, and the autocovariance at various lags do not change across time (Wooldridge, 2013). According to Granger and Newbold (1974), when the regression is performed among non-stationary variables, then the regression result will be spurious as shown by the high goodness of fit $\left(R^{2}\right)$ and significant $t$-statistics; but it does not have any substantive economic relationship (Enders, 2015; Hamilton, 1994). Next, the Granger causality test will be applied to examine the relationship between the variables under the assumption that the time series are stationary (Gujarati, 2003). The Granger causality test is performed to test whether one variable can be used to help the forecast of another variable. Then, if one variable could help to forecast another variable, it can be said that one variable Granger causes another variable. If not, one variable is not Granger caused by another variable. Specifically, if there is a one-way relationship between the variables, it is called unidirectional causality, whereas when a two-way relationship is present, it is called bidirectional causality. Furthermore, the existence of Granger causality among variables enables the past and current values of one variable to help forecast the future value of another variable.

Finally, the impulse response function and forecast error variance decomposition will be analyzed. Enders (2015) defined impulse response function as a tool to trace out the impact of the shocks on the variables contained in the VAR model over time. The impulse response function that will use in this study is the Cholesky decomposition. However, this type of impulse response function needs the order of the variables from variables that affect most of the other variables to the variable that affect other variables less. The impulse response function shows through the graph containing one line in the middle and two dashed lines. The dashed lines define the confidence interval of $95 \%$. In line with the impulse response function, the forecast error variance decomposition shows the contribution of the impact on one variable due to self-incurred shocks as well as the shocks from other variables. 


\section{Result and Discussion}

The estimation strategy that described earlier will apply in this study. Following a unit root test, the vector autoregression model estimated. Then, the Granger causality test, impulse response function, and forecast error variance decomposition will be applied.

Both the informal and formal tests to identify the stationarity or unit root will perform in this paper. First, informal test conduct by plotting the time series into a graph (Gujarati, 2003). The plot of each variable will show the fluctuation of each series over time or if there is any specific trend of the series. Then, the prediction of the stationarity of the series can obtain. Regarding the formal test, two standard unit root tests will perform in this paper, namely the Augmented Dickey-Fuller test and Phillips-Perron test. The Augmented DickeyFuller test can be used to test the unit roots for serial correlation that includes a higher order of autoregression terms in the equation. Whereas the Phillips-Perron test can be used to test the existence of a unit root when there is a possibility of serial correlation in the residual and a possibility of heteroscedasticity (Hamilton, 1994).

\section{Figure 1. The Results of Plot of Each Variable} LN_RGDP
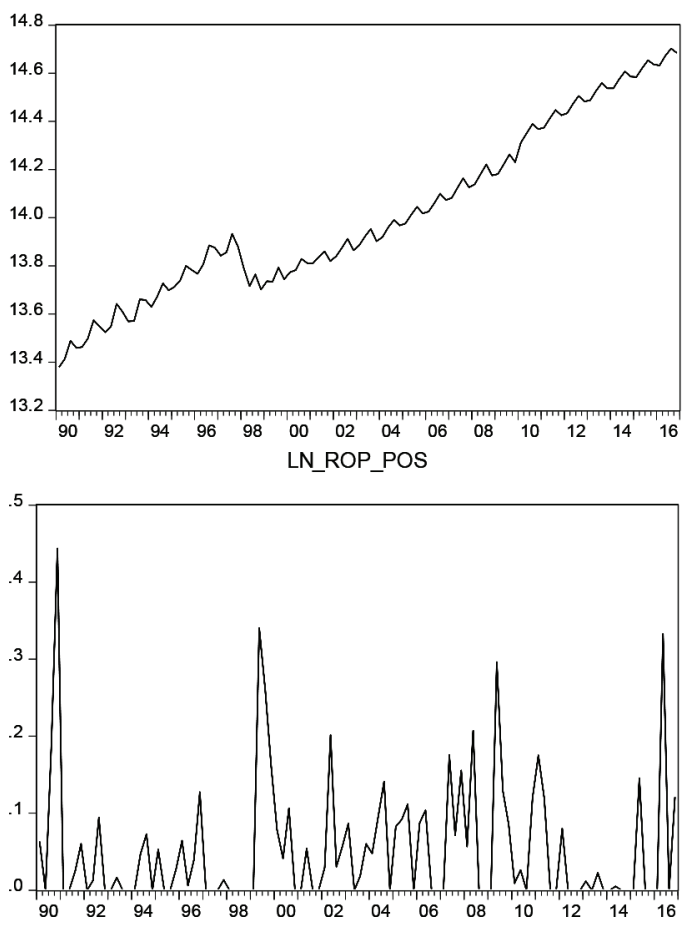

CPI
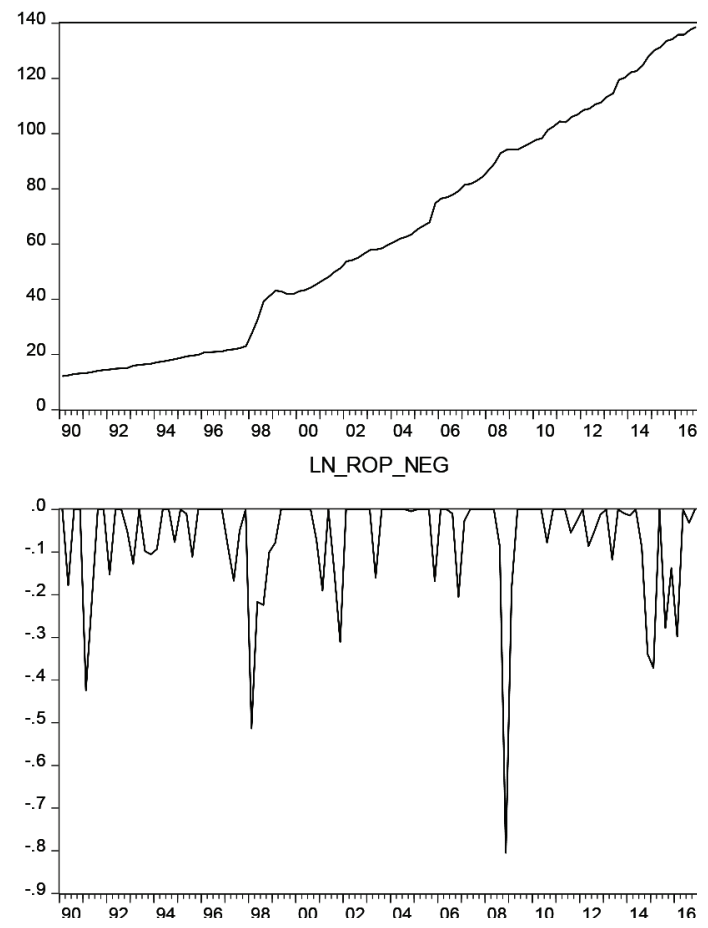

First, plotting each variable into the graph checked the unit root of each variable. Figure 1 shows that both the real GDP and consumer price index indicate an increasing trend, meaning that the mean is not constant or varies over time, whereas both the positive and negative changes in oil price show fluctuation. Next, the statistical method was used to confirm the graphical result. Then, the Augmented Dickey-Fuller (ADF) and Phillips-Perron (PP) test were performed to check the existence of the unit root of each variable.

Table 4 shows the result of the ADF test and PP test to check the presence of a unit root for 
each variable. As shown in the table, the results for both the ADF and PP tests at a level for two variables, which are real GDP in the natural logarithmic form and consumer price index, cannot reject the null hypothesis of a unit root (non-stationary) at all critical values. The conclusion base on the result that the t-statistic (in absolute value) is less than the critical value. Then, the null hypothesis of a unit root (non-stationary) will fail to reject. Meanwhile, the results of both the ADF and PP tests at the level of the other two variables which are positive and adverse changes in the real oil price in the natural logarithmic form reject the null hypothesis of a unit root (non-stationary) at all critical values. It is because the t-statistic (in absolute value) is higher than the critical value (in absolute value); so, the null hypothesis of a unit root (non-stationary) reject. In other words, both the real GDP in the natural logarithmic form and consumer price index are non-stationary in level, whereas both the positive and negative changes in the real oil price in the natural logarithmic form are stationary in level.

Table 4. Unit Root Tests in Level

\begin{tabular}{|c|c|c|c|c|c|c|c|}
\hline \multicolumn{2}{|c|}{ Variables } & \multirow[t]{2}{*}{ ADF Test } & \multirow[t]{2}{*}{ PP Test } & \multicolumn{3}{|c|}{ Critical Values } & \multirow[t]{2}{*}{ Results } \\
\hline & & & & $1 \%$ & $5 \%$ & $10 \%$ & \\
\hline \multirow[t]{2}{*}{ In_rgdp } & Intercept & 0.336 & -0.183 & -3.496 & -2.890 & -2.582 & Unit Root \\
\hline & $C \& T$ & -1.600 & -2.251 & -4.051 & -3.454 & -3.153 & Unit Root \\
\hline \multirow[t]{2}{*}{ сpi } & Intercept & 1.607 & 2.062 & -3.493 & -2.889 & -2.581 & Unit Root \\
\hline & $C \& T$ & -2.688 & -2.671 & -4.047 & -3.453 & -3.152 & Unit Root \\
\hline In_rop_pos & Intercept & $-8.597^{* * *}$ & $-8.546^{* * *}$ & -3.493 & -2.889 & -2.581 & No Unit Root \\
\hline In_rop_neg & Intercept & $-8.330^{* * *}$ & $-8.304^{* * *}$ & -3.493 & -2.889 & -2.581 & No Unit Root \\
\hline
\end{tabular}

Note. ${ }^{* * *}$ denotes the rejection of null hypothesis at level $5 \%$. C\&T refers to constant and trend.

However, a series with a trend or non-stationarity could be transformed into a stationary series by differencing. A series will be transformed into the first difference when it is stationary in the first difference form. It is also true that the series will be transformed into the $d$ th difference when the series is stationary in the $d$ th difference form. The series is also integrated with order $d$ and is denoted by I (d) (Enders, 2015). Another consideration is that if the variables in the equation are stationary in the same level of difference form or integrated in the same order, and the residual or linear combination is stationary, then the variables are cointegrated (Enders, 2015; Hamilton, 1994).

When a series of the real GDP in the natural logarithmic form and consumer price index transform into the first difference; both the ADF and PP tests reject the null hypothesis of a unit root (non-stationary). In other words, both the real GDP in the natural logarithmic form and consumer price index are stationary in the first difference.

It can conclude that both the positive and negative changes in the real oil price in the natural logarithmic form integrate to the order zero, $\mathrm{I}(0)$, whereas both the real GDP in the natural logarithmic form and consumer price index integrate to the order one, I(1). It is implied that both the positive and negative changes in the real oil price in the natural 
logarithmic form are stationary in level, while both the real GDP in the natural logarithmic form and consumer price index are stationary in the first difference. Based on in Tabel 4 and Table 5, the cointegration test to check the existence of a cointegrating relationship among variables could not conduct because all the variables are not integrated in the same order.

Table 5. Unit Root Tests in the First Difference

\begin{tabular}{|c|c|c|c|c|c|c|c|}
\hline \multirow{2}{*}{\multicolumn{2}{|c|}{ Variables }} & \multirow{3}{*}{$\begin{array}{l}\text { ADF Test } \\
-3.913^{* * *}\end{array}$} & \multirow{3}{*}{$\begin{array}{c}\text { PP Test } \\
-11.787^{* * *}\end{array}$} & \multicolumn{3}{|c|}{ Critical Values } & \multirow{3}{*}{$\begin{array}{c}\text { Results } \\
\text { No Unit Root }\end{array}$} \\
\hline & & & & \multirow{2}{*}{$\begin{array}{c}1 \% \\
-3.496\end{array}$} & \multirow{2}{*}{$\begin{array}{c}5 \% \\
-2.890\end{array}$} & \multirow{2}{*}{$\begin{array}{c}10 \% \\
-2.582\end{array}$} & \\
\hline dln_rgdp & Intercept & & & & & & \\
\hline dcpi & Intercept & $-6.897^{* * *}$ & $-6.943^{* * *}$ & -3.493 & -2.889 & -2.581 & No Unit Root \\
\hline
\end{tabular}

Note. ${ }^{* * *}$ denotes the rejection of null hypothesis at level $5 \%$. C\&T refers to constant and trend.

Following the methods used by Ferderer (1996), Huang et al. (2005), and Rafiq, et al. (2009), as some variables are stationary in level and some other variables are stationary in the first difference. The vector autoregression model will incorporate the variables of positive changes in the real oil price and the negative changes in the real oil price, the real GDP in the first difference, and the consumer price index in the first difference. To analyze the asymmetric impact of oil price changes on GDP and inflation. This VAR model is also suggested by Luetkepohl (2011), as VAR models can perform either in the level when all variables are I(0) or some or all variables in the first difference when some variables are $\mathrm{I}(1)$ or all variables are $\mathrm{I}(1)$, and there is no co-integration among the variables.

Then, the estimated VAR can use for the forecasting purpose after the estimation of the VAR model has been performed (Enders, 2015). Sims (1980) suggested that the relevant economic model should select the variables incorporated in a VAR system, and the appropriate lag length should select according to the lag length tests. Furthermore, in order to solve the spuriousness problem, Hamilton (1994) also suggested that the lagged value of variables should be included. The appropriate lag length could examine the likelihood ratio test (Enders, 2015). However, this test is not appropriate for a small sample in a time series analysis. Alternatively, the Akaike information criterion (AIC) and the Schwartz Bayesian criterion (SBC) could be applied. The model that has the lowest value of AIC and SBC will be used.

Table 6 shows the results of the lag order selection. Lag 5 is chosen to include in the vector autoregression model. Because of most of the criteria, which include the likelihood ratio (LR), final prediction error (FPE), and Akaike's information criterion (AIC), results identify lag five as an appropriate lag; whereas, the Hannan and Quinn information criterion (HQ) result shows that lag 4 is appropriate. The Schwarz's information criterion (SC) result suggests that lag 0 is appropriate for the vector autoregression model. Also, lag 5 is chosen based on the fact that the impact of changes in oil price does not have an immediate effect on the Indonesian economy. It takes some lag time for the world oil price to be translated into the domestic fuel price as determined by the government, which will later affect the economic activities in Indonesia. Therefore, lag 5 will be included in the vector autoregression model as suggested by most of the criteria related to the Indonesian condition. 
Table 6. VAR Lag Order Selection Criteria

\begin{tabular}{ccccccc}
\hline Lag & LogL & LR & FPE & AIC & SC & HQ \\
\hline 0 & 224.9373 & NA & $1.35 \mathrm{e}-07$ & -4.463381 & $-4.358527^{*}$ & -4.420957 \\
1 & 242.3077 & 32.98614 & $1.32 \mathrm{e}-07$ & -4.491065 & -3.966798 & -4.278946 \\
2 & 272.4497 & 54.80366 & $9.92 \mathrm{e}-08$ & -4.776762 & -3.833082 & -4.394947 \\
3 & 292.6937 & 35.17145 & $9.14 \mathrm{e}-08$ & -4.862500 & -3.499407 & -4.310990 \\
4 & 331.0906 & 63.60699 & $5.86 \mathrm{e}-08$ & -5.314963 & -3.532456 & $-4.593758^{*}$ \\
5 & 349.6458 & $29.23844^{*}$ & $5.63 \mathrm{e}-08^{*}$ & $-5.366582^{*}$ & -3.164662 & -4.475682 \\
6 & 355.7226 & 9.084423 & $7.01 \mathrm{e}-08$ & -5.166112 & -2.544779 & -4.105517 \\
7 & 364.2125 & 12.00593 & $8.38 \mathrm{e}-08$ & -5.014393 & -1.973647 & -3.784102 \\
8 & 377.6181 & 17.87418 & $9.14 \mathrm{e}-08$ & -4.961982 & -1.501822 & -3.561996 \\
\hline
\end{tabular}

Note. ${ }^{*}$ indicates the lag order selected by the criterion.

The result of the Granger causality test is report in Table 7. Since the paper investigates the asymmetric impact of oil price changes on GDP and inflation, it will focus on the result of the Granger causality of the positive and negative changes in the real oil price in the natural logarithmic form. The results failed to reject the null hypothesis that the independent variables do not Granger cause the dependent variables, implying that both the positive and negative changes in the real oil price in the natural logarithmic form do not Granger cause either GDP or inflation. Moreover, as the positive and negative changes in the real oil price in the natural logarithmic form, the results failed to reject the null hypothesis that the independent variables do not Granger cause the dependent variables, implying that both GDP and inflation do not Granger cause either positive or negative change in the real oil price in the natural logarithmic form.

Table 7. Granger Causality Test

\begin{tabular}{ccccc}
\hline \multirow{2}{*}{$\begin{array}{c}\text { Independent } \\
\text { Variables }\end{array}$} & First equation & Second equation & Third equation & Fourth equation \\
\cline { 2 - 4 } & \multicolumn{3}{c}{ Dependent Variables } \\
\cline { 2 - 4 } & dlnrgdp & dcpi & In_rop_neg & In_rop_pos \\
\hline dlnrgdp & - & 7.723866 & 4.125448 & 10.30210 \\
& & $(0.1721)$ & $(0.5315)$ & $(0.0671)$ \\
dcpi & 11.33273 & - & 3.807130 & 5.344523 \\
& $(0.0452)^{* * *}$ & & $(0.5775)$ & $(0.3753)$ \\
In_rop_neg & 8.477344 & 3.254412 & - & 15.00635 \\
& $(0.1318)$ & $(0.6608)$ & & $(0.0103)^{* * *}$ \\
In_rop_pos & 6.111561 & 3.213131 & 4.234165 & - \\
& $(0.2955)$ & $(0.6672)$ & $(0.5162)$ & \\
\hline
\end{tabular}

Note. The numbers in parentheses represent $\mathrm{p}$-value. ${ }^{* * *}$ denote $5 \%$ level of significance.

These results show that when investigating the asymmetric impact of oil price changes on GDP and inflation of Granger causality, there is no Granger causality among the variables. This result suggests that both the positive and negative changes in the real oil price in the natural logarithmic form cannot help in predicting both the GDP and inflation and vice 
versa. These findings are consistent with Cunado and Gracia's (2005) that also find that the changes in the real oil price did not Granger cause the economic growth rates in the Asian countries they studied. Besides that, the only Granger caused the inflation rates in some of the covered countries. Whereas the changes in oil prices expressed in domestic currency significantly Granger caused both the economic growth and inflation in most of the covered countries. This result explains that the real oil price change expressed in US\$ cannot directly help forecast the GDP and inflation express in local currency.

The graphs of orthogonalized impulse response function perform the response of one variable to the shock of one standard deviation of another variable over a period of 10 quarters. The impulse definition that will use is the Cholesky decomposition. In this type of impulse, the variables need to order from the most influential (most exogenous) to the least influential variables (least exogenous).

In this paper, the order for the Cholesky decomposition decided by first testing Chang and Wong's (2003) assumption that a shock of oil price has a direct impact on inflation and an indirect effect on GDP. Two sets of orders tested as follows: (a) the positive changes in oil price accompanied by the negative changes in oil price, inflation, and GDP; and (b) the negative changes in oil price followed by the positive changes in oil price, inflation, and GDP. The results showed that there were no significant differences in the impulse response functions for both the sets. Based on these results as well as the suggestion of Jbir and Zouari-Ghorbel (2009), the following order was decided: downward changes in oil price (ln_rop_neg), upward changes in oil price (ln_rop_pos), consumer price index (dcpi), and real GDP (dln_rgdp).

Figure 2. The Results of The Impulse Response Function

Response to Cholesky One S.D. Innovations \pm 2 S.E.

Response ofDLN_RGDP to LN_ROP_NEG

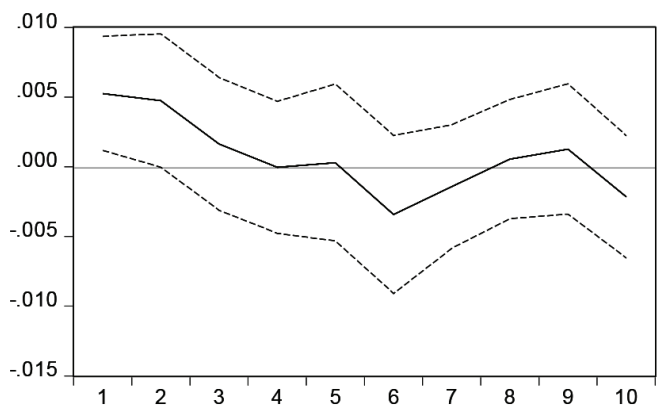

Response of DCPI to LN_ROP_NEG

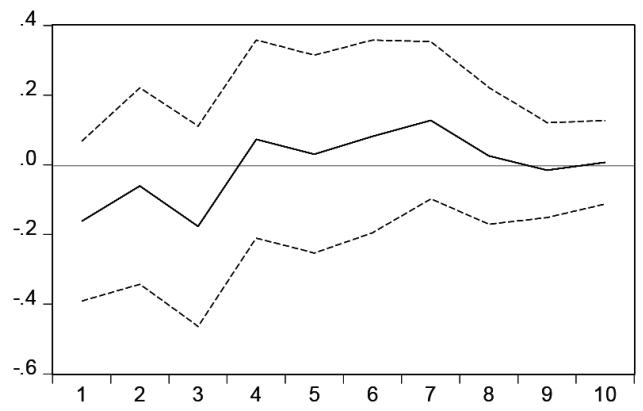

Response of DLN_RGDP to LN_ROP_POS

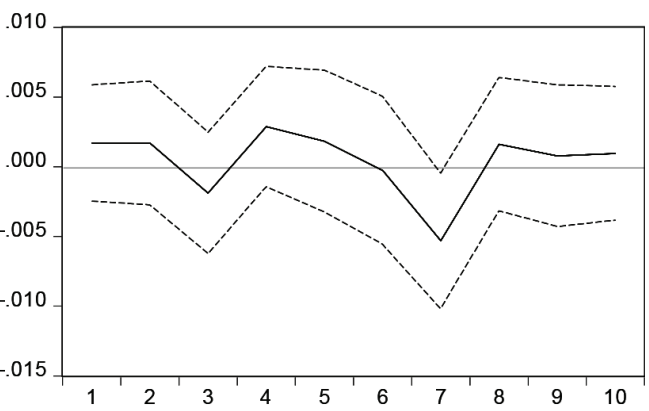

Response of DCPI to LN_ROP_POS

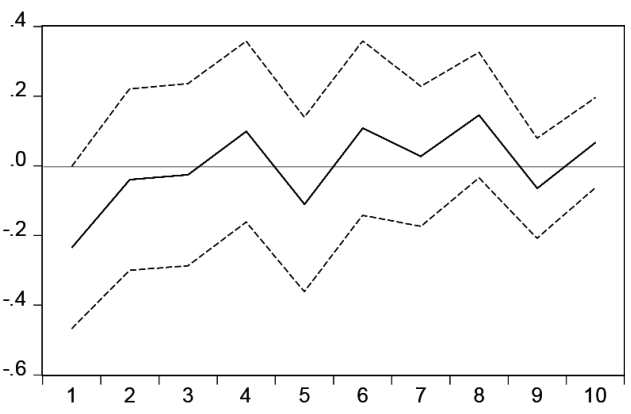


In the output graph of the impulse response function, the middle line in Figure 2 shows the impulse response function and the dashed line represents the confidence interval. When the zero (horizontal line) locate between the confidence interval, it implies that the impact is not different from zero or not significant because the null hypothesis that oil price shocks do not affect GDP and inflation has failed to reject.

Since there are four variables, there are 16 graphs of impulse response function correspondingly, which presented in Appendix 1. To highlight the findings of the structural form of the asymmetric impact of oil price changes on GDP and inflation, four graphs on the response of GDP and inflation to the shock of positive and negative changes in oil price presented in Figure 2.

First, the impulse response function of the real GDP in the natural logarithmic form in the first difference was traced out. Figure 2 showed that the shocks of the negative changes in the real oil price significantly decreased the real GDP for the first two quarters after the initial shock. The results showed that Indonesia's GDP was disadvantaged by the downward changes in oil price. Meanwhile, the real GDP was not significantly affected by the shocks of positive changes in the real oil price because the impact is not different from zero. Considering the impulse response of the consumer price index, a shock of one standard deviation of both the negative and positive changes in the real oil price did not significantly affect the consumer price index for 10 quarters.

Such findings confirm that the asymmetric impact of oil price changes on GDP exist in the case where a shock of positive changes in the real oil price did not significantly affect the GDP, whereas a shock of negative changes in oil price significantly decreased the GDP in the immediate period. The decreasing and significant impact of negative changes in the real oil price on GDP is not consistent with the theory that the decreased oil price will increase GDP. The positive changes in the real oil price do not affect GDP. The inconsistency of this result with the theory suggests that Indonesia's GDP still depends on oil as a significant source of revenue. Another finding is that Indonesia's GDP is more vulnerable to the downward changes in oil price, as the contribution of downward changes in oil price is larger than the contribution of upward changes in oil price to GDP. It can explain that Indonesia's GDP is more sensitive to the downward changes in oil price because of the contribution of the oil and gas sector to it. Indonesia's GDP has been decreasing over a period regardless of oil price fluctuations. This declining trend of the contribution could result from the decline of the total production of oil, as it is a non-renewable source that depletes over time. However, oil as a source of revenue still plays an important role; so, the downward changes in oil price will disadvantage Indonesia's GDP, whereas upward changes in oil price will not significantly affect Indonesia's GDP.

Meanwhile, the impact of both the positive and negative changes in oil price on inflation was not significant, which can consider as the symmetry impact of oil price changes on inflation. The statistically not so significant impact of both the positive and negative changes in the real oil price on inflation can be considered to be resulting from the implementation of the fuel price subsidy policy in Indonesia. With the fuel price subsidy, the retail price of fuel is subsidized and determined by the government to lower the impact of the world price 
fluctuations of oil on the consumer price. So, when there is an oil price fluctuation, the retail fuel price will not change direction and proportionately to the change in oil price, and the consumer price index will not be affected directly either. Therefore, the direct relationship between inflation and the changes in oil price could not be explained or is not significant. As a result, the impact of oil price changes on inflation is considered to be symmetric, or the asymmetric impact of oil price changes on inflation is considered not to exist.

Figure 3. The results of forecast error variance decomposition of the real GDP in the natural logarithmic form in the first difference

Variance Decomposition

PercentDLN_RGDP variance due to DLN_RGDP

PercentDLN_RGDP variance due to DCP
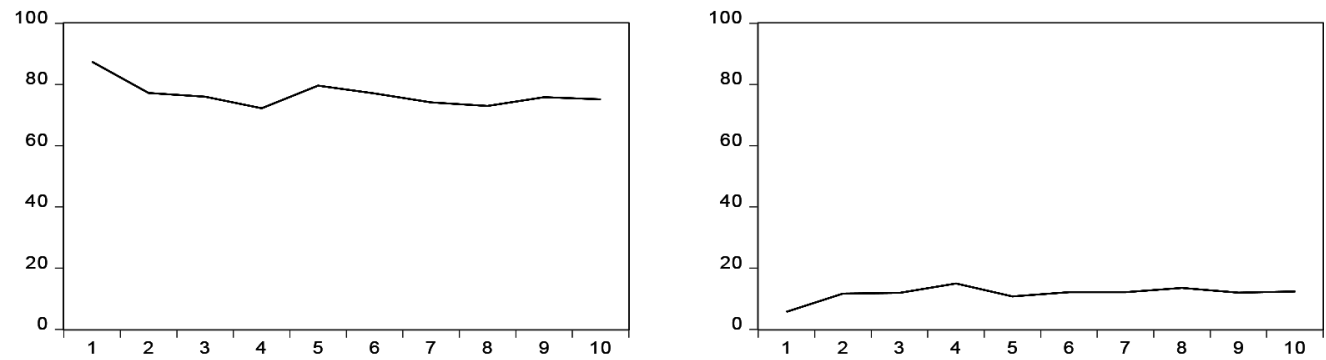

Percent DLN_RGDP variance due to LN_ROP_NEG

PercentDLN_RGDP variance due to LN_ROP_POS
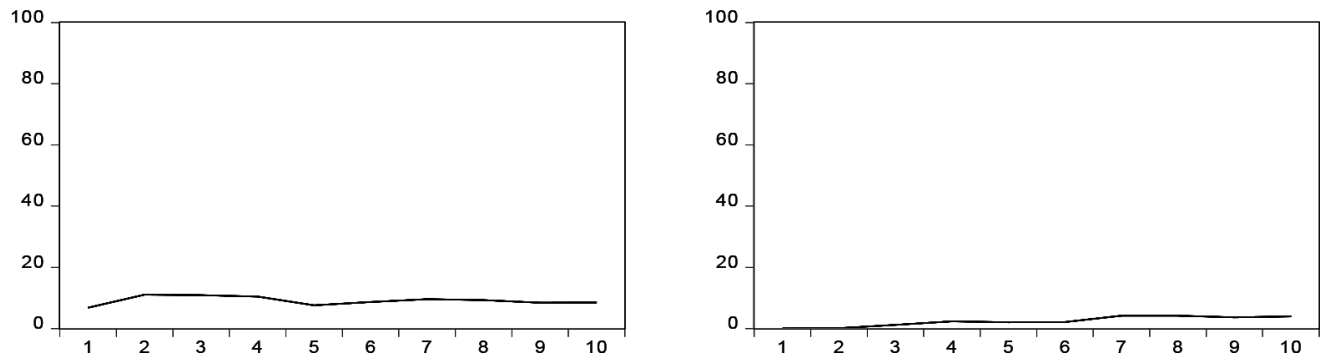

The contribution of the impact of each variable can capture by forecast error variance decomposition, which is presented graphically in Figure 3 and Figure 4. Figure 3 shows that the contribution of the impact of the adverse change in real oil prices on the real GDP was 11\% in the second quarter, which was the highest proportion of the effect. Meanwhile, the positive change in real oil prices only contributed by about $4 \%$ as the maximum contribution of the total impact on real GDP captured in the eight quarters. Regarding the proportion of the effect on inflation, Figure 4 shows that the negative change in real oil price contributed by about $7 \%$ in the tenth quarter that was the maximum contribution. Similarly, the impact of the positive change in real oil prices only committed for a maximum 3.3\% on inflation in the tenth quarter.

Forecast error variance decomposition (in appendix 2) helps to trace out the proportion of the impact of each variable. For example, the result of forecast error variance decomposition helps to explain that the positive changes in real oil price did not significantly affect the inflation or GDP because of the contribution, as compared to the total impact, is small in proportion. Similarly, the effect of the negative changes in oil price on inflation was not significant due to the negligible contribution of the impact. Meanwhile, the significant effect of the negative changes in the real oil price on GDP accounted for $11 \%$. 
Figure 4. The results of forecast error variance decomposition of the consumer price index in the first difference.

Variance Decomposition

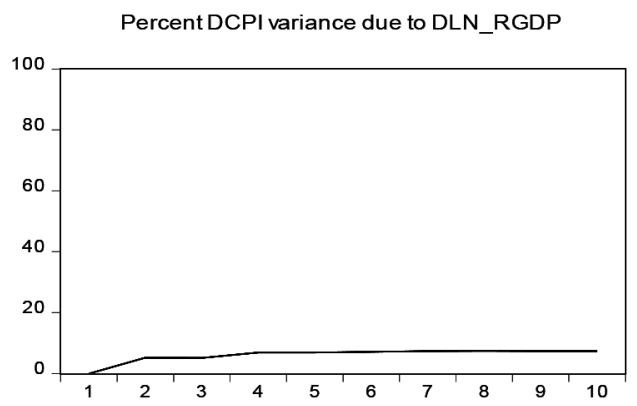

Percent DCPI variance due to DCPI

Percent DCPI variance due to LN ROP NEG
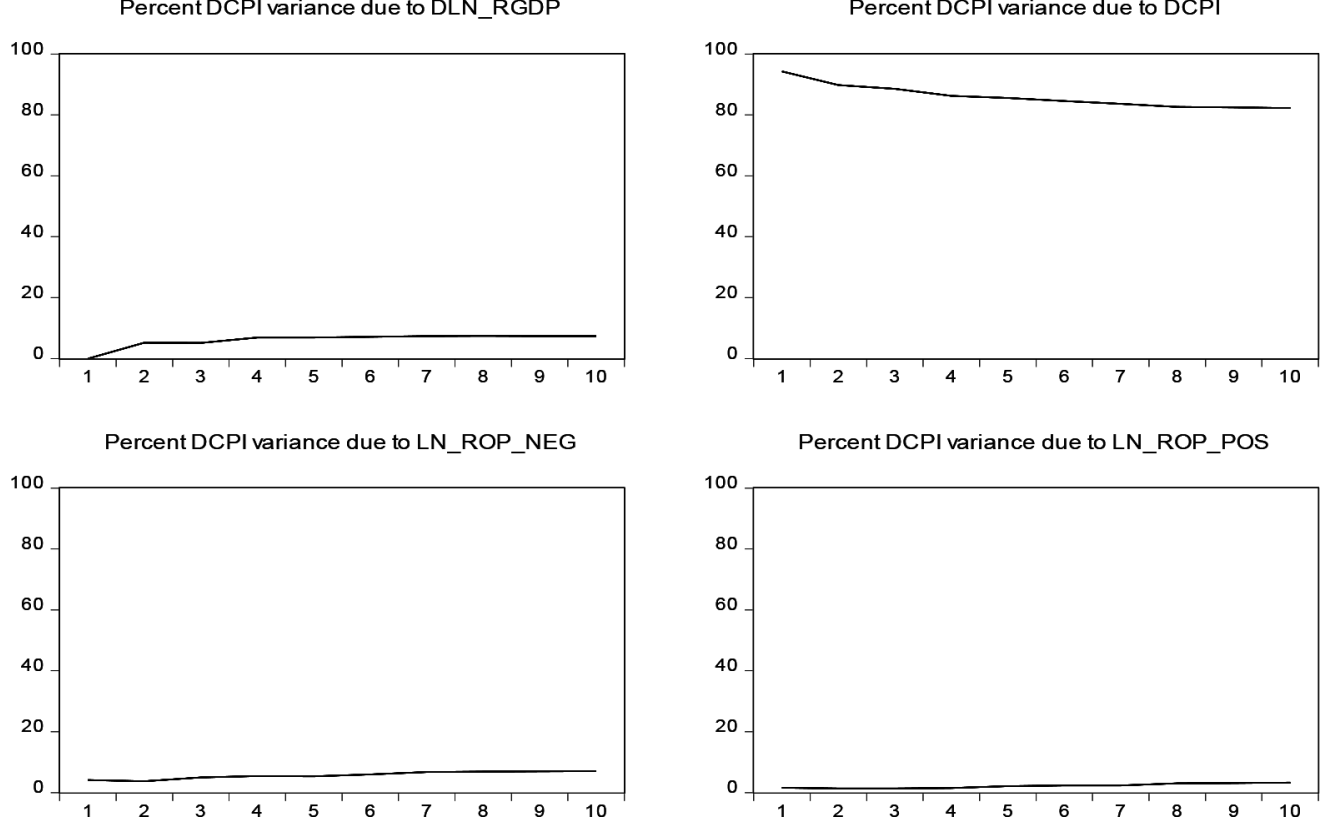

\section{Conclusion}

This paper analyzes the asymmetric impact of oil price changes on the GDP of and inflation in Indonesia from 1990Q1 to 2016Q4. The asymmetric effect of price change can define as the effect of the same change in price that does not have the same magnitude when the change is positive as compared to when the change is negative. Specifically, the asymmetry of the impact of oil price changes is studied by separating the changes in oil price into positive and negative changes. Then, the effect of both the positive and negative changes in oil price on GDP and inflation were investigated using the vector autoregression model, impulse response function and forecast error variance decomposition. The results can be summarized as follows:

This study further examines the asymmetric effects by applying both the impulse response function and forecast error variance decomposition. The asymmetric impact of oil price changes on GDP exists in the case where a shock of positive changes in the real oil price did not significantly affect the GDP, whereas a shock of negative changes in oil price significantly decreased the GDP. Meanwhile, the impact of both the positive and negative changes in oil price on inflation was not significant, which can consider as the symmetry impact of oil price changes on inflation. Although the results are not consistent with the theory that the changes in oil price will negatively affect GDP and positively affect inflation, the results to explain the impact of oil price changes on the Indonesian economy, particularly GDP and inflation.

The results of this study can lead to important policy recommendations. The Indonesian government should take into account the asymmetric impact of oil price changes. Considering the effect of changes in oil price on GDP, the decreased oil price would depress the GDP significantly, and the increased oil price will not affect the GDP. 
Therefore, the impact of the changes in oil prices on the Indonesian economy can reduce by lowering the dependency on oil as a significant source of revenue, despite the decline of the contribution of oil to the income over the years. Indonesia has been transforming itself from a net oil exporter to a net oil importer since 2005; therefore, the oil revenue measured as the percentage of the total GDP has decreased by about 50\% from 1990 to 2005 and account for less than $1 \%$ in 2015, as shown in Table 2. Thus, utilizing and diversifying energy sources other than oil also to include renewable energy source can be a solution to reduce the dependency on oil and the impact of oil price fluctuations. Regarding inflation, although the results indicate that inflation is not significantly affected by the changes in oil price, the Indonesian government should focus more on the fluctuation in oil price to control inflation, particularly after 2015 as the phasing out of the fuel subsidy started. As the fuel subsidy gets phased out, the domestic fuel prices will fluctuate according to the international oil price, which means the fluctuations in domestic fuel price also can affect inflation in the future.

However, more research needs to further investigate the impact of oil price changes on GDP and inflation. Events that occurred in Indonesia such as its transformation from a net oil exporter to a net oil importer and the deregulation of fuel subsidy policy should more explicitly incorporate into the analysis. Data with greater coverage is needed to more accurately assess the impact of these events. Then, the further research incorporating such events would improve our understanding of the effect of changes in oil price and help inform policy better.

\section{References}

Abeysinghe, T. (2001). Estimation of Direct and Indirect Impact of Oil Price on Growth. Economic Letters, 73: 147-153.

Brown, S., \& Yucel, M. (2002). Energy Prices and Aggregate Economic Activity: An Interpretative Survey. The Quarterly Review of Economics and Finance. 42 (2): 193-208.

Chang, Y., \& Wong, J. F. (2003). Oil Price Fluctuations and Singapore Economy. Energy Policy. 31 (11): 1151-1165. doi: 10.1016/S0301-4215(02)00212-4.

Cologni, A., \& Manera, M. (2008). Oil Prices, Inflation and Interest Rates in a Structural Cointegrated VAR Model for the G-7 countries. Energy Economics. 30 (3): 856-888.

Cuñado, J., \& de Gracia, F. P. (2003). Do Oil Price Shocks Matter? Evidence for Some European Countries. Energy Economics. 25 (2): 137-154.

Cuñado, J., \& de Gracia, F. P. (2005). Oil Prices, Economic Activity and Inflation: Evidence for Some Asian Countries. The Quarterly Review of Economics and Finance. 45 (1): 6583.

Cunado, J., Jo, S., \& Gracia, F. P. (2015). Macroeconomic impacts of oil price shocks in Asian economies. Energy Policy, 86, 867-879.

Du, L., He, Y., \& Wei, C. (2010). The relationship between oil price shocks and China's macro-economy: An empirical analysis. Energy Policy. 38 (8): 4142-4151. 
Enders, W. (2015). Applied econometric time series (4th ed.). New Jersey: Wiley.

Farzanegan, M. R., \& Markwardt, G. (2009). The Effects of Oil Price Shocks on The Iranian Economy. Energy Economics. 31 (1): 134-151.

Ferderer, J. P. (1996). Oil Price Volatility and the Macroeconomy. Journal of Macroeconomics. Vol. 18 (1): 1-26.

Gujarati, D. N. (2003). Basic Econometrics (4th ed.). New York: McGraw-Hill.

Hamilton, J. D. (1983). Oil and the Macroeconomy since World War II. Journal of Political Economy. 91 (2): 228-248.

Hamilton, J. D. (1994). Time Series Analysis. Princeton, New Jersey: Princeton University Press.

Huntington, H. G. (1998). Crude Oil Prices and U.S. Economic Performance: Where does The Asymmetry Reside? The Energy Journal. 19(4): 107-132.

Jbir, R., \& Zouari-Ghorbel, S. (2009). Recent Oil Price Shock and Tunisian Economy. Energy Policy. 37(3): 1041-1051.

Lee, K., Ni, S., \& Ratti, R. A. (1995). Oil Shocks and the Macroeconomy: The Role of Price Variability. The Energy Journal. 16 (4): 39-56.

Luetkepohl, H. (2011). Vector Autoregressive Models. EUI Working Papers.

Mork, K. A. (1989). Oil and The Macroeconomy when Prices Go Up and Down: An Extension of Hamilton's Results. Journal of Political Economy. 97 (3): 740-744.

Mork, K. A., Olsen, O., \& Mysen, H. T. (1994). Macroeconomic Responses to Oil Price Increases and Decreases in Seven OECD Countries. The Energy Journal. 15(4): 19-35.

National Energy Council. (2015). Kebijakan energi nasional [National energy policy]. Jakarta.

Rafiq, S., Salim, R., \& Bloch, H. (2009). Impact of Crude Oil Price Volatility on Economic Activities: An Empirical Investigation in The Thai Economy. Resources Policy. 34(3): 121-132.

Sims, C. A. (1980). Macroeconomics and Reality. Econometrica. 48 (1): 1-48.

Wooldridge, J. M. (2013). Introductory Econometrics: A Modern Approach (5th ed.). Mason, Ohio: South-Western Cengage Learning. 


\section{Appendix 1. Impulse Response Function}

Response to Cholesky One S.D. Innov ations \pm 2 S.E.
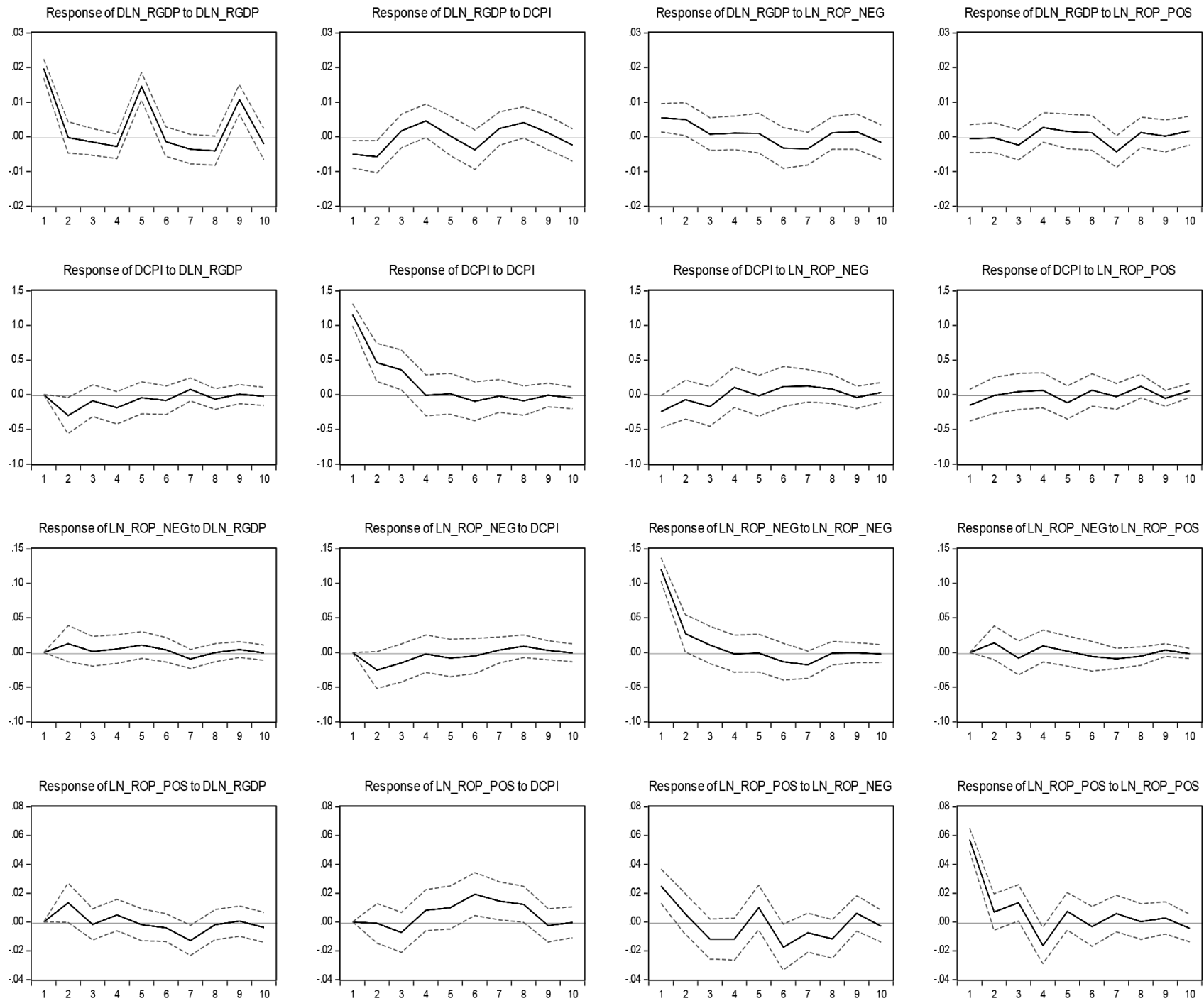


\section{Appendix 2. Forecast Error Variance Decomposition}

Variance Decomposition of DLN_RGDP:

\begin{tabular}{cccccc} 
Period & S.E. & DLN_RGDP & DCPI & LN_ROP_NEG & LN_ROP_POS \\
\hline 1 & 0.021060 & 87.39184 & 5.733657 & 6.809537 & 0.064964 \\
2 & 0.022404 & 77.22816 & 11.63845 & 11.05393 & 0.079456 \\
3 & 0.022654 & 75.96751 & 11.92834 & 10.91932 & 1.184827 \\
4 & 0.023459 & 72.24112 & 14.97086 & 10.40466 & 2.383360 \\
5 & 0.027688 & 79.61650 & 10.75635 & 7.600330 & 2.026824 \\
6 & 0.028187 & 77.06610 & 12.15351 & 8.667839 & 2.112544 \\
7 & 0.029038 & 74.15440 & 12.10738 & 9.557599 & 4.180612 \\
8 & 0.029648 & 72.98609 & 13.50772 & 9.315826 & 4.190364 \\
9 & 0.031610 & 75.88087 & 12.01537 & 8.413022 & 3.690736 \\
10 & 0.031858 & 75.13217 & 12.40057 & 8.536538 & 3.930731
\end{tabular}

Variance Decomposition of DCPI:

\begin{tabular}{cccccc} 
Period & S.E. & DLN_RGDP & DCPI & LN_ROP_NEG & LN_ROP_POS \\
\hline 1 & 1.188020 & 0.000000 & 94.23641 & 4.155445 & 1.608144 \\
2 & 1.312220 & 5.213564 & 89.75461 & 3.705523 & 1.326299 \\
3 & 1.374438 & 5.149511 & 88.57352 & 4.951855 & 1.325111 \\
4 & 1.392820 & 6.857766 & 86.25508 & 5.404671 & 1.482487 \\
5 & 1.398297 & 6.907424 & 85.58895 & 5.375946 & 2.127676 \\
6 & 1.410401 & 7.126711 & 84.58304 & 5.977971 & 2.312275 \\
7 & 1.418562 & 7.329325 & 83.63218 & 6.718386 & 2.320104 \\
8 & 1.430259 & 7.400069 & 82.64386 & 6.932389 & 3.023683 \\
9 & 1.431820 & 7.386549 & 82.46497 & 6.995853 & 3.152631 \\
10 & 1.434365 & 7.386107 & 82.28022 & 7.023614 & 3.310059
\end{tabular}

Variance Decomposition of LN_ROP_NEG:

\begin{tabular}{cccccc} 
Period & S.E. & DLN_RGDP & DCPI & LN_ROP_NEG & LN_ROP_POS \\
\hline 1 & 0.119942 & 0.000000 & 0.000000 & 100.0000 & 0.000000 \\
2 & 0.127003 & 1.005166 & 3.998389 & 93.81137 & 1.185078 \\
3 & 0.128643 & 0.995595 & 5.288344 & 92.15167 & 1.564389 \\
4 & 0.129112 & 1.134295 & 5.276723 & 91.50831 & 2.080675 \\
5 & 0.129816 & 1.795681 & 5.598578 & 90.52474 & 2.081001 \\
6 & 0.130781 & 1.852391 & 5.669998 & 90.24684 & 2.230770 \\
7 & 0.132647 & 2.318443 & 5.578088 & 89.49444 & 2.609029 \\
8 & 0.133058 & 2.304567 & 5.997583 & 88.94743 & 2.750422 \\
9 & 0.133204 & 2.396144 & 6.040059 & 88.75418 & 2.809615 \\
10 & 0.133232 & 2.395897 & 6.039157 & 88.73891 & 2.826041 \\
\hline
\end{tabular}




\begin{tabular}{cccccc}
\hline $\begin{array}{c}\text { Variance Decomposition of LN_ROP_POS: } \\
\text { Period }\end{array}$ & S.E. & DLN_RGDP & DCPI & LN_ROP_NEG & LN_ROP_POS \\
\hline 1 & 0.062370 & 0.000000 & 0.000000 & 15.92249 & 84.07751 \\
2 & 0.064370 & 4.240222 & 0.025451 & 15.65009 & 80.08424 \\
3 & 0.067208 & 3.952227 & 1.193729 & 17.50114 & 77.35291 \\
4 & 0.070812 & 4.014364 & 2.381915 & 18.62131 & 74.98241 \\
5 & 0.072595 & 3.892283 & 4.148242 & 19.59390 & 72.36558 \\
6 & 0.077322 & 3.706217 & 9.941031 & 22.39870 & 63.95405 \\
7 & 0.080295 & 5.999640 & 12.50556 & 21.65346 & 59.84134 \\
8 & 0.082092 & 5.796551 & 14.16592 & 22.78777 & 57.24975 \\
9 & 0.082394 & 5.758590 & 14.15322 & 23.14482 & 56.94337 \\
10 & 0.082645 & 5.934378 & 14.06849 & 23.12665 & 56.87048
\end{tabular}

Cholesky Ordering: LN_ROP_NEG LN_ROP_POS DCPI DLN_RGDP 